\title{
Enfermagem em Foco retorna à cena
}

Desde 2013 estamos com dificuldades de publicar a revista em dia. Isto, infelizmente se deve a fatores os quais não temos controle. No entanto, a partir de 2016, essa realidade mudará, pois já temos contratada a empresa que realizará a editoração e impressão da revista.

De forma a diminuir os prejuízos para os autores que submeteram manuscritos em nossa plataforma e que tiveram um atraso na resposta, o Conselho Editorial decidiu reunir mais de um fascículo num mesmo volume. Assim, por exemplo este fascículo contempla o volume 5/ 2014.

A partir do volume 6/2015, também concentrado retornamos ao cenário das publicações com a revista nos dois suportes: eletrônico e impresso. Este volume relativo a 2015 entra em circulação em fevereiro. Já março de 2016 publicaremos o primeiro fascículo de 2016, se constituindo de um número temático que abordará os resultados da pesquisa Perfil da Enfermagem no Brasil. Trabalho realizado pela Fiocruz patrocinado pelo Conselho Federal de Enfermagem.

Enfermagem em Foco permanece na posição B2 do Qualis periódicos da Capes. Ainda que, ao acessar a plataforma Sucupira não encontremos a revista, no entanto, a coordenadora da área de Enfermagem da Capes, Dra Carmen Scochi nos assegurou essa posição. Quanto à ausência na plataforma, ela justificou que há problemas de compatibilidade na migração de planilhas para o sistema, e reitera que logo estará solucionado. Ficamos na expectativa!

Para manter a revista viva são necessárias as contribuições dos pesquisadores da nossa profissão. De forma que solicitamos que submetam trabalhos à revista, temos um compromisso de dar celeridade ao processo de avaliação, para tanto implementamos mudanças nas normas de publicação, introduzimos a tradução qualificada, selecionando um grupo de tradutores, aos quais os autores poderão contatar para verter seus artigos em inglês e espanhol.

Também renovamos nosso corpo de avaliadores para termos uma maior abrangência de temas, bem como representatividade no âmbito dos programas de pós-graduação e de regiões do Brasil. Mantivemos os consultores internacionais, visto que são importantes para dar visibilidade ao periódico no cenário mundial de publicações.

Ainda em âmbito internacional temos garantido a participação de representante da revista na International of Nursing Editors-INANE, organização de editores que se reúne anualmente em uma conferência. Deste encontro emanam orientações que repercutem em todo o mundo editorial da enfermagem, inclusive no em nosso país.

Assim, com o desejo de melhorar a publicação da Enfermagem em Foco é que solicitamos aos nossos leitores que nos enviem artigos para avaliação. A submissão é on-line em no site.

\section{Boa Leitura!}

Joel Rolim Mancia

Editor-Chefe

Universidade do Vale dos Sinos-UNISINOS 